\title{
Benign Pleural Mesothelial Cells Have Higher Osmotic Water Permeability than Malignant Pleural Mesothelioma Cells and Differentially Respond to Hyperosmolality
}

\author{
Liubov E. Katkova ${ }^{a}$ Galina S. Baturina ${ }^{a}$ Alexander A. Bondar \\ Rajesh M. Jagirdarc Chrissi Hatzoglou ${ }^{c, d}$ Konstantinos I. Gourgoulianis ${ }^{d}$ \\ Evgeniy I. Solenove,e,f Sotirios G. Zarogiannis ${ }^{c, d}$
}

\begin{abstract}
anstitute of Cytology and Genetics, SB RAS, Novosibirsk, Russia, ' Institute of Chemical Biology and Fundamental Medicine, SB RAS, Novosibirsk, Russia, 'Department of Physiology, Faculty of Medicine, University of Thessaly, BIOPOLIS, Larissa, Greece, dDepartment of Respiratory Medicine, Faculty of Medicine, University of Thessaly, BIOPOLIS, Larissa, Greece, eNovosibirsk State University, Novosibirsk,

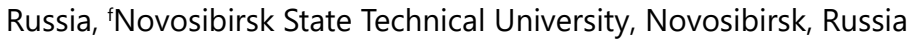

\section{Key Words}

AQP1 • Hyperosmotic stress • Malignant pleural mesothelioma • Osmotic water permeability - Pleural mesothelial cells

\begin{abstract}
Background/Aims: Cell volume regulation is a critical mechanism for cell homeostasis and depends on the osmotic water permeability $\left(P_{f}\right)$ of the cell plasma membrane. The $P_{f}$ of human mesothelial cells is unknown although they contribute to serosal fluid turnover. Methods: In this study we measured the osmotic water permeability of benign human mesothelial cells (MeT-5A) and of epithelioid (M14K) and sarcomatoid (ZL34) malignant pleural mesothelioma (MPM) cells in response to acute hyperosmotic stress. We also assessed the changes in their $\mathrm{P}_{\mathrm{f}}$ after preconditioning with $4 \%$ glucose for 24 hours. In both cases we also assessed the role of AQP1 inhibition $(0.1 \mathrm{mM} \mathrm{HgCl})$ on the $P_{f}$ Finally, we assessed corresponding changes in the AQP1 plasma membrane availability by immunofluorescence. Results: We report that MeT-5A cells have a significantly higher $P_{f}$ as compared to M14K and ZL34 MPM cells $[4.85 \mathrm{E}-03 \pm 2.37 \mathrm{E}-03 \mathrm{~cm} / \mathrm{sec}(\mathrm{n}=17)$ versus $2.74 \mathrm{E}-03 \pm 0.74 \mathrm{E}-03 \mathrm{~cm} / \mathrm{sec}(\mathrm{n}=11)$ and $2.86 \mathrm{E}-03 \pm 0.11 \mathrm{E}-03 \mathrm{~cm} / \mathrm{sec}(n=11)]$. AQP1 inhibition significantly decreased the $P_{f}$ in all cells lines $(p<0.001$ in all cases). High glucose preconditioning for 24 hours significantly increased MeT-5A $P_{f}(p<0.001)$, did not influence M14K $P_{f}(p=0.19)$ and significantly reduced ZL34 $P_{f}$ $(p=0.02)$. Comparing cell lines after high glucose preconditioning, MeT-5A $\mathrm{P}_{f}$ was significantly higher than that of M14K and ZL34 MPM cells and the AQP1 inhibition effect was significant

G. Baturina and L.E. Katkova contributed equally to this work.

\begin{tabular}{ll}
\hline S.G. Zarogiannis & Department of Physiology, Faculty of Medicine, University of Thessaly, BIOPOLIS \\
& 41500, Larissa (Greece) \\
& Tel. +302410685558 , Fax +302410685555 , E-Mail szarog@med.uth.gr
\end{tabular}
\end{abstract}




\section{Cellular Physiology Cell Physiol Biochem 2019;52:869-878 \\ \begin{tabular}{ll|l} 
and Biochemistry & $\begin{array}{l}\text { DOl: 10.33594/000000060 } \\
\text { Published online: } 9 \text { April 2019 }\end{array}$ & $\begin{array}{l}\text { O } 2019 \text { The Author(s). Published by } \\
\text { Cell Physiol Biochem Press GmbH\&Co. KG }\end{array}$ \\
\cline { 2 - 3 }
\end{tabular} \\ Katkova et al.: Osmotic Water Permeability of Pleural Mesothelial Cells}

in MeT-5A and M14K cells. These results were corroborated by AQP1 immunofluorescence. Conclusion: We provide evidence for a differential regulation of $P_{f}$ in benign and MPM cells that require further mechanistic investigation.

\section{Introduction}

Pleural mesothelial cells are specialized epithelial cells of mesodermal origin lining the lungs (visceral pleura) and the thoracic wall (parietal pleura) and between which the pleural cavity is formed [1]. Under physiological conditions, a small amount of pleural fluid is present in the cavity, produced by plasma ultrafiltration from the parietal pleura capillaries $[2,3]$. It is re-absorbed by the parietal pleura lymphatic stomata, by Starling forces across the visceral pleura and by mesothelial cell-mediated solute coupled liquid absorption and endocytosis $[2,3]$. In several extra-pulmonary (e.g. congestive heart failure, malignancy, post-myocardial infarction, rheumatoid arthritis] and pulmonary diseases [e.g. pneumonia, lung cancer, malignant pleural mesothelioma (MPM), pulmonary embolism] pleural effusions occur (excess accumulation of pleural fluid in the pleural cavity) [4]. Depending on the underlying pathology, protein, glucose, lactate dehydrogenase and $\mathrm{pH}$ pleural fluid levels vary; as is the case for cytokines and growth factors that are produced locally either by pleural mesothelial cells or by leucocytes [2-8]. Thus, the pleural mesothelial cells in pathophysiological conditions can encounter various biochemical environments that may influence their functions e.g. production of cytokines, cell migration, adhesion, proliferation, mesothelial to mesenchymal transition, transport of ions [9-13].

Due to the role of pleural mesothelial cells in pleural fluid absorption, it is important to study their plasma membrane water permeability. Several studies have shown that pleural mesothelial cells express aquaporin-1 (AQP1) that plays a role in the equilibration of the osmotic gradient between the pleural cavity and the pleural capillaries in pleural effusions [3, 10, 14]. Moreover, in MPM patients the high tumor expression of AQP1 has been described as a favorable prognostic factor regarding survival $[15,16]$. We previously showed a differential in the AQP1 expression with respect to MPM histological subtype (epithelioid, biphasic and sarcomatoid); more AQP1 being expressed in the least aggressive form of MPM, the epithelioid subtype [17]. Moreover, MPM AQP1 inhibition in vitro inhibits cell adhesion, migration and tumor sphere formation in an extracellular component type and histological type dependent manner [10]. Furthermore, AQP1 inhibition in MPM leads to decreased cell proliferation, motility and metastatic potential [18].

Glucose was shown to induce the expression of AQP1 in human peritoneal mesothelial cells in vitro [19]. Diabetes Mellitus (DB) is a common comorbidity in MPM [20], however no study has assessed the role of AQP1 in MPM cells osmotic water permeability $\left(\mathrm{P}_{\mathrm{f}}\right)$ under high glucose osmotic stress. In the same context, in DB patients the development of pleural effusions is significantly more common than in non-diabetic patients [21].

Based on the above, the aim of our study was to assess the osmotic regulation of $P_{f}$ of benign mesothelial cells and epithelioid and sarcomatoid MPM cells under norm-osmotic and high glucose hyper-osmotic conditions and by AQP1 inhibition to evaluate the contribution of this channel in transmembrane water transport.

\section{Materials and Methods}

\section{Cell culture}

The human cell lines MeT-5A (benign immortalized mesothelial cells), M14K (epithelioid MPM), and ZL34 (sarcomatoid MPM) were used in the study. Cell culture was performed in RPMI-1640 cell medium supplemented with $10 \% \mathrm{BCS}, 1 \%$ antibiotics, and $1 \%$ L-glutamine in a $5 \% \mathrm{CO}_{2}$ humidified incubator at $37^{\circ} \mathrm{C}$. The hypertonic medium for the measurement of water permeability was created by $300 \mathrm{mOsm} \mathrm{kg}^{-1}$ mannitol in PBS. Control cells were maintained in normal medium while glucose preconditioned cells were 


\section{Cellular Physiology Cell Physiol Biochem 2019;52:869-878 \\ \begin{tabular}{ll|l} 
and Biochemistry & $\begin{array}{l}\text { DOl: 10.33594/000000060 } \\
\text { Published online: } 9 \text { April 2019 }\end{array}$ & $\begin{array}{l}\text { O } 2019 \text { The Author(s). Published by } \\
\text { Cell Physiol Biochem Press GmbH\&Co. KG }\end{array}$ \\
\cline { 2 - 3 }
\end{tabular} \\ Katkova et al.: Osmotic Water Permeability of Pleural Mesothelial Cells}

maintained in a $4 \%$ glucose $(\mathrm{w} / \mathrm{v})$-culture medium for 24 hours prior to each experiment. All chemicals were purchased from Sigma-Aldrich unless otherwise stated.

\section{Water permeability measurements}

Fluorescence measurements of cell volume were performed by the calcein quenching method as previously described $[22,23]$. Cell volume changes were expressed as relative values of calcein fluorescence, an established surrogate of the cell volume fluctuations [24, 25]. Cells were grown on cover glasses and loaded with Calcein-AM (5 $\mu \mathrm{M}, 15 \mathrm{~min}$ at $37^{\circ} \mathrm{C}$; Invitrogen, CA, USA). The fluorescence of calcein was continuously measured with a LED light source, through a filter set \#09 (BP 450 - $490 \mathrm{~nm}$ excitation, FT 510 $\mathrm{nm}$ dichroic mirror, LP $515 \mathrm{~nm}$ emission), a photomultiplier detector with a pinhole diaphragm in order to be able to select the cells of interest and with a 12-bit analog-to-digital converter PCL-818HG (Advantech). The data acquisition rate was set to $10 \mathrm{msec}$. A superfusion chamber was constructed as an acrylic block with T-shape current of cell medium. This design makes fast change of superfusion medium feasible and minimizes the perturbations of the specimens. The flow rate of the perfusate was set to $20 \mathrm{~mL} / \mathrm{min}$, which resulted in a complete solution exchange in the area of interest in less than $50 \mathrm{msec}$. The chamber was mounted on the stage of an inverted microscope (Axiovert 40, Zeiss, Germany; objective lens with 40x magnification; numerical aperture 0.65 ; thermal stabilization at $36.8 \pm 0.2^{\circ} \mathrm{C}$ ). The water permeability was calculated from the rate of the cell volume changes under the osmotic challenge on the basis of the equation [25]: $d V / d t=-A V_{w} P_{f} \nabla \Phi$. The plasma membrane osmotic water permeability coefficient $\left(\mathrm{P}_{f}\right)$ was calculated from the time course of the cell volume change in response to an osmotic gradient. The osmotic water movement is the net flow of volume across a cell membrane in response to hydrostatic and/or osmotic pressure: $J=-L_{p} A \Delta \Phi$; or $d V / d t=-P_{f} A V_{w} \Delta C$. The permeability coefficient can be calculated from the slope $\left(\mathrm{K}_{\mathrm{r}}\right)$ of the linear plot [26]: $\mathrm{P}_{\mathrm{f}}=\mathrm{K}_{\mathrm{r}}\left[A V_{\mathrm{w}}\left(\mathrm{C}_{\text {in }}-\mathrm{C}_{\text {out }}\right)\right]^{-1}$. Where $\mathrm{J}$ is the rate of volume flow across the membrane $\left(\mathrm{cm}^{3}\right.$ $\left.\mathrm{s}^{-1}\right),(\mathrm{dV} / \mathrm{dt})$ is the rate of cell volume change, $\mathrm{L}_{\mathrm{p}}$ is hydraulic conductivity $\left(\mathrm{cm}^{3} \mathrm{~s}^{-1} \mathrm{~atm}^{-1}\right), \mathrm{P}_{\mathrm{f}}$ is the osmotic water permeability coefficient $\left(\mathrm{cm} \mathrm{s}^{-1}\right), A$ is the surface area $\left(\mathrm{cm}^{2}\right)$ which is significant for water exchange, $\Delta \Phi$ is the osmotic pressure difference (atm), $\Delta \mathrm{C}$ is the osmotic concentration difference $\left(\mathrm{Osm} \mathrm{kg}^{-1}\right)$, and $\mathrm{V}_{\mathrm{w}}$ is the partial molar volume of water. In the water permeability measurements, the cells were washed with PBS and were then incubated with a calcein-PBS solution for 20 minutes at $37^{\circ} \mathrm{C}$. Then were incubated in a solution of PBS supplemented with $300 \mathrm{mOsm} \mathrm{kg}^{-1}$ of mannitol for $30 \mathrm{sec}$ (in order to balance) and then the solution was rapidly replaced with normal PBS $\left(300 \mathrm{mOsm} \mathrm{kg}^{-1}\right)$ and the apparent water permeability was measured. In experiments assessing the role of AQP1 in the apparent water permeability mercuric chloride $\left(\mathrm{HgCl}_{2} ; 0.1 \mathrm{mM}\right)$ was used to inhibit AQP1.

\section{Immunostaining}

The rabbit polyclonal anti-AQP1 antibody (\#ab15080; Abcam) was used. Cells were fixed for 30 minutes by incubation on ice with 4\% paraformaldehyde on PBS and processed for immunostaining. Briefly, glasses were blocked in PBS containing 1\% non fat milk for 30 minutes and incubated with the primary antibody at $4^{\circ} \mathrm{C}$ overnight. After 3 washes with PBS, incubation with the goat anti-rabbit IgG FITC secondary antibody followed (\#554020; BD Biosciences) for 2 hours at room temperature. Pictures were taken using an Observer Z1 fluorescence microscope (Zeiss, Germany).

\section{Statistical analyses}

Data are presented as means $\pm S D$. Statistical significance was evaluated using unpaired $t$ test with Welch correction when comparing for two variables and One-Way ANOVA when comparing three variables. A value of $p<0.05$ was considered significant. 


\section{Results}

The $P_{f}$ of human benign pleural mesothelial cells is significantly higher than that of MPM cells

The apparent water permeability $\left(\mathrm{P}_{f}\right)$ of benign and malignant mesothelial cells was assessed after the reaction of the cells to a rapid switch from a hyperosmotic medium $\left(600 \mathrm{mOsm} \mathrm{kg}^{-1}\right)$ to a normosmotic medium $\left(300 \mathrm{mOsm} \mathrm{kg}^{-1}\right)$. As shown in Fig. $1 \mathrm{~A}$, the $\mathrm{P}_{\mathrm{f}}$ of MeT-5A cells was $4.85 \mathrm{E}-03 \pm 2.37 \mathrm{E}-03 \mathrm{~cm} / \mathrm{sec}(\mathrm{n}=17)$ that was significantly higher ( $\mathrm{p}<0.01$ in both cases) than both M14K $(2.74 \mathrm{E}-03 \pm 0.74 \mathrm{E}-03 \mathrm{~cm} / \mathrm{sec} ; \mathrm{n}=11)$ and ZL34 cells (2.86E-03 $\pm 0.11 \mathrm{E}-03 \mathrm{~cm} / \mathrm{sec} ; \mathrm{n}=11)$.

The $P_{f}$ of human benign and malignant pleural mesothelial cells is mediated by the function of $A Q P 1$

$\mathrm{HgCl}_{2}$ was used to assess the $\mathrm{P}_{\mathrm{f}}$ of benign and malignant pleural mesothelial cells during concomitant inhibition of AQP1 by $\mathrm{HgCl}_{2}$ treatment. As shown in Fig. 1B-D, in all the three cell lines tested, the inhibition of AQP1 resulted in a significant decrease of the $\mathrm{P}_{\mathrm{f}}$. More specifically, in MeT-5A cells the $P_{f}$ reduced to $2.15 \mathrm{E}-03 \pm 0.92 \mathrm{E}-03 \mathrm{~cm} / \mathrm{sec}(\mathrm{n}=21 ; \mathrm{p}<0.001$ compared to untreated; Fig. 1B), in M14K cells the $P_{f}$ was reduced to 8.63E-04 $\pm 0.32 \mathrm{E}-04$ $\mathrm{cm} / \sec \left(\mathrm{n}=11 ; \mathrm{p}<0.001\right.$ compared to untreated; Fig. 1C) and ZL34 MPM cells the $\mathrm{P}_{\mathrm{f}}$ was reduced to $1.14 \mathrm{E}-03 \pm 0.44 \mathrm{E}-03 \mathrm{~cm} / \mathrm{sec}(\mathrm{n}=18 ; \mathrm{p}<0.001$ compared to untreated; Fig. 1D).

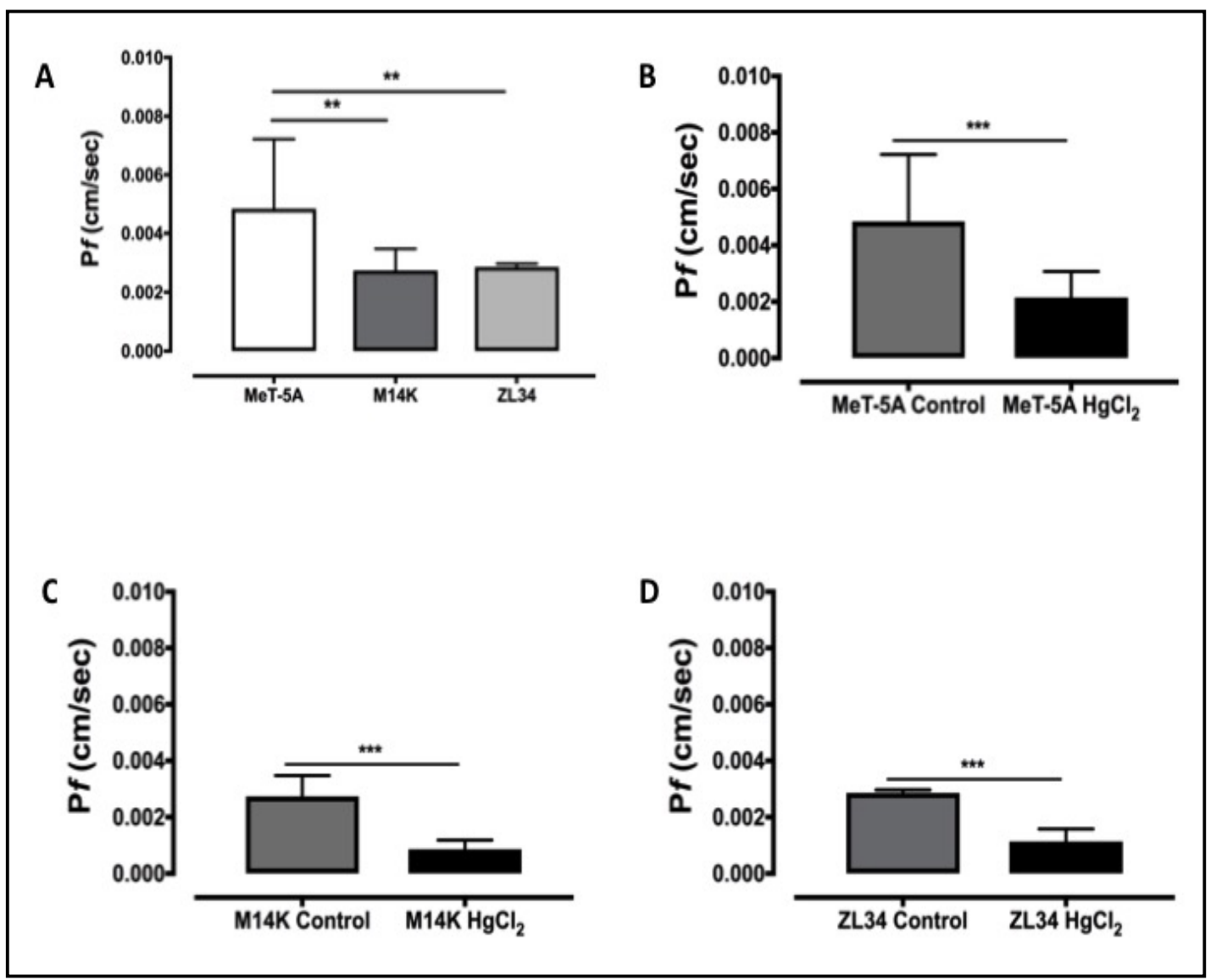

Fig. 1. (A). Osmotic water permeability $\left(\mathrm{P}_{\mathrm{f}}\right.$ ) of benign (MeT-5A) and malignant (M14K and ZL34) mesothelial cells. ${ }^{* *} \mathrm{p}<0.01$ as compared to MeT-5A. Comparison of $\mathrm{P}_{\mathrm{f}}$ of MeT-5A (B), M14K (C) and ZL34 (D) cells without and with inhibition of AQP1 by $\mathrm{HgCl}_{2}{ }^{* * *} \mathrm{p}<0.001$ compared to no treatment. 
High glucose hyperosmotic stress for 24 hours significantly increased the $P_{f}$ of MeT-5A, did not influence M14K cells $P$ while it significantly decreased the $P_{f}$ of ZL34 cells

As shown in Fig. 2, exposure of cells to $4 \%$ glucose containing cell medium for 24 hours resulted in significantly higher $\mathrm{P}_{\mathrm{f}}$ values in MeT-5A cells to $1.41 \mathrm{E}-02 \pm 1.11 \mathrm{E}-02 \mathrm{~cm} /$ sec $(n=30 ; p<0.001$ compared to Control). In M14K cells this effect was not significantly different $3.59 \mathrm{E}-03 \pm 2.33 \mathrm{E}-03$ $\mathrm{cm} / \mathrm{sec} \quad(\mathrm{n}=16 ; \quad \mathrm{p}=0.19$ compared to Control). Finally, in ZL34 cells the hyperosmotic stress led to a significant decrease of the $\mathrm{P}_{\mathrm{f}}$ values to $1.74 \mathrm{E}-03 \pm 1.24 \mathrm{E}-03 \mathrm{~cm} / \mathrm{sec}$ $(\mathrm{n}=10 ; \mathrm{p}=0.02$ compared to Control).

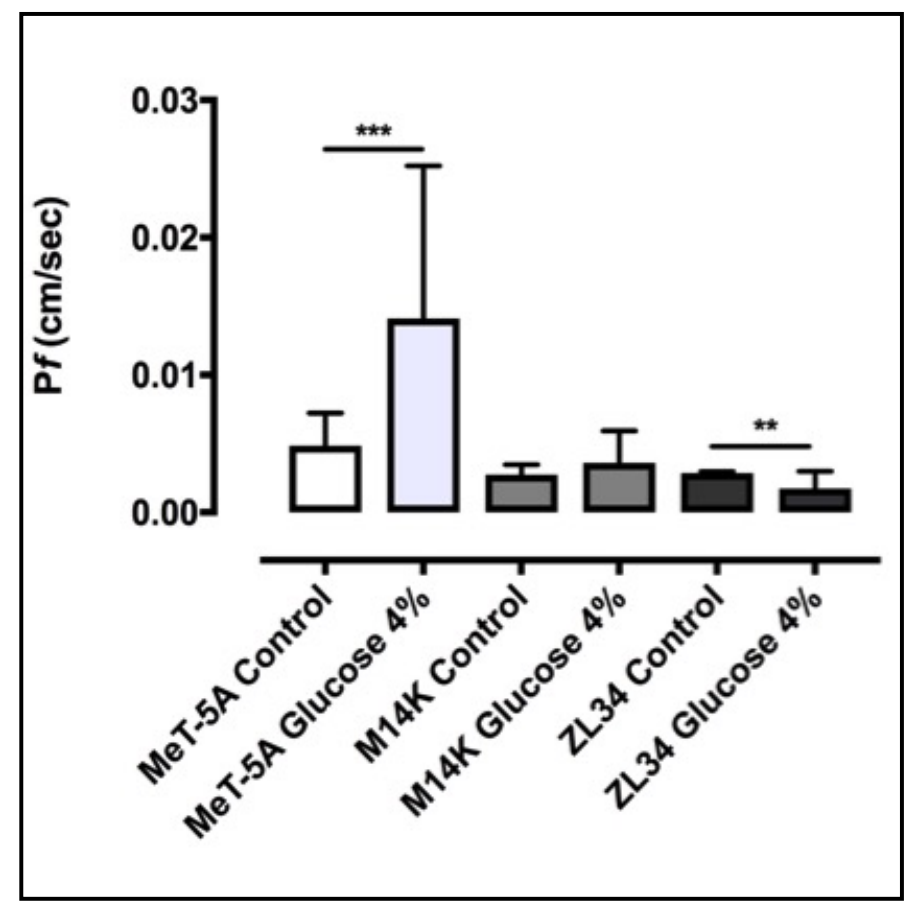

Fig. 2. Comparison of the Pf of each cells line after high glucose hyperosmotic stress for 24 hours. Differential effects of glucose are shown depending on the cell line. ${ }^{* *} \mathrm{p}<0.01$ and ${ }^{* * *} \mathrm{p}<0.001$ compared to respective control.

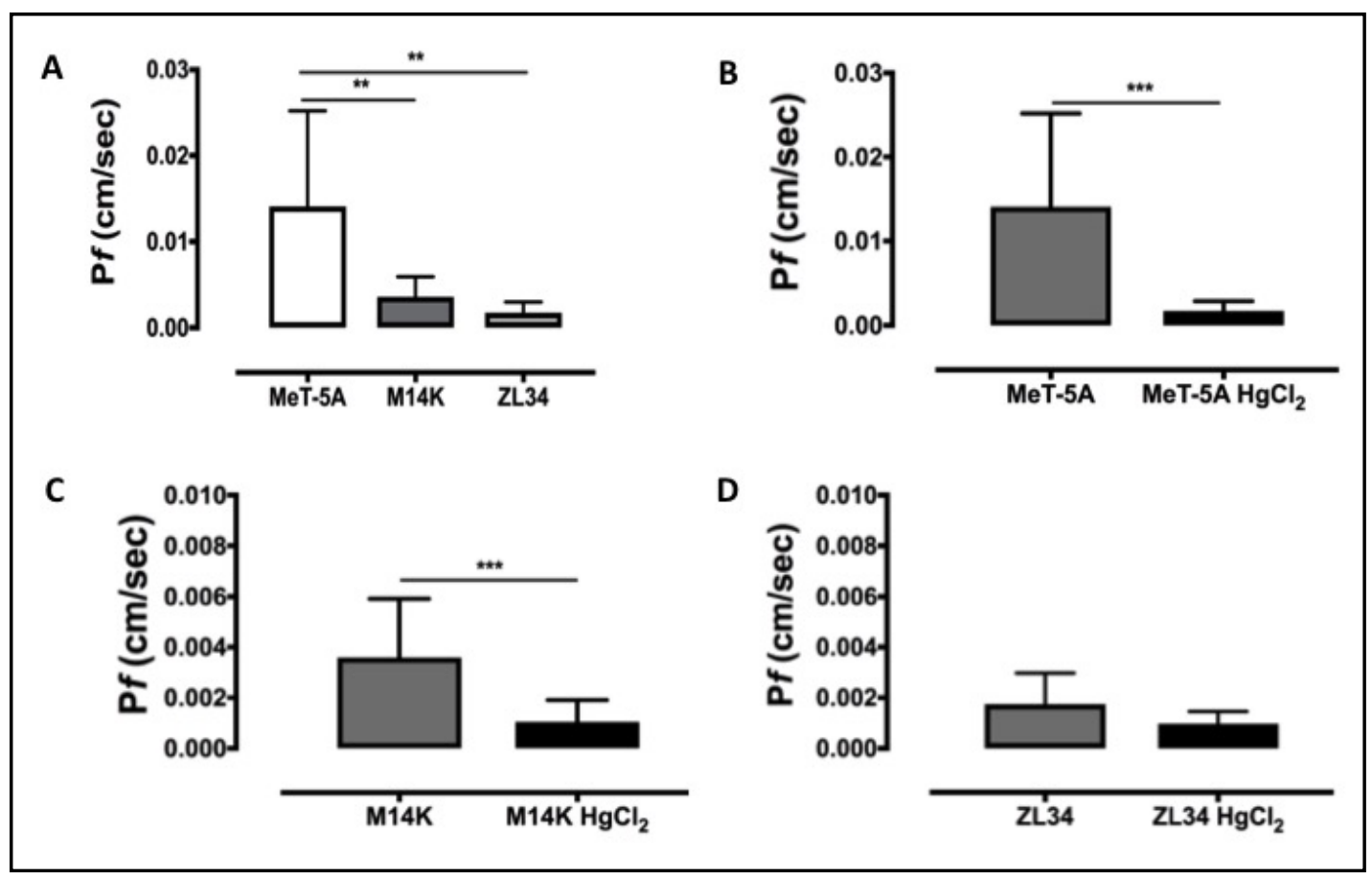

Fig. 3. (A). Osmotic water permeability $\left(\mathrm{P}_{\mathrm{f}}\right)$ of benign (MeT-5A) and malignant (M14K, ZL34) mesothelial cells that were exposed to high glucose hyper-osmotic stress for 24 hours. ${ }^{* *} \mathrm{p}<0.01$ as compared to MeT-5A. Comparison of $\mathrm{P}_{\mathrm{f}}$ of MeT-5A (B), M14K (C) and ZL34 (D) cells without and with inhibition of AQP1 by $\mathrm{HgCl}_{2}$. ${ }^{* * *} \mathrm{p}<0.001$ compared to no treatment. 


\section{Cellular Physiology}

and Biochemistry

The $P_{f}$ of human benign pleural mesothelial cells is significantly higher than that of MPM cells after high glucose hyperosmotic stress for 24 hours and is mediated by AQP1 in benign and epithelioid MPM cells

The $\mathrm{P}_{f}$ of benign and malignant pleural mesothelial cells was also assessed after a 24hour high glucose hyperosmotic stress with and without AQP1 by $\mathrm{HgCl}_{2}$. As shown in Fig. 3A, the $\mathrm{P}_{\mathrm{f}}$ of MeT-5A cells was $1.41 \mathrm{E}-02 \pm 1.11 \mathrm{E}-02 \mathrm{~cm} / \mathrm{sec}(\mathrm{n}=30)$ that was significantly higher $(\mathrm{p}<0.01$ in both cases) than both M14K (3.59E-03 $\pm 2.33 \mathrm{E}-03 \mathrm{~cm} / \mathrm{sec} ; \mathrm{n}=16)$ and ZL34 cells $(1.74 \mathrm{E}-03 \pm 1.24 \mathrm{E}-03 \mathrm{~cm} / \mathrm{sec} ; \mathrm{n}=10)$. As far as the inhibition of AQP1 is concerned it resulted in a significant decrease of the $\mathrm{P}_{\mathrm{f}}$ in benign cells and epitheliod MPM cells. More specifically, in MeT-5A cells the $\mathrm{P}_{\mathrm{f}}$ reduced to $1.71 \mathrm{E}-03 \pm 1.16 \mathrm{E}-03 \mathrm{~cm} / \mathrm{sec}(\mathrm{n}=12 ; \mathrm{p}<0.001$ compared to

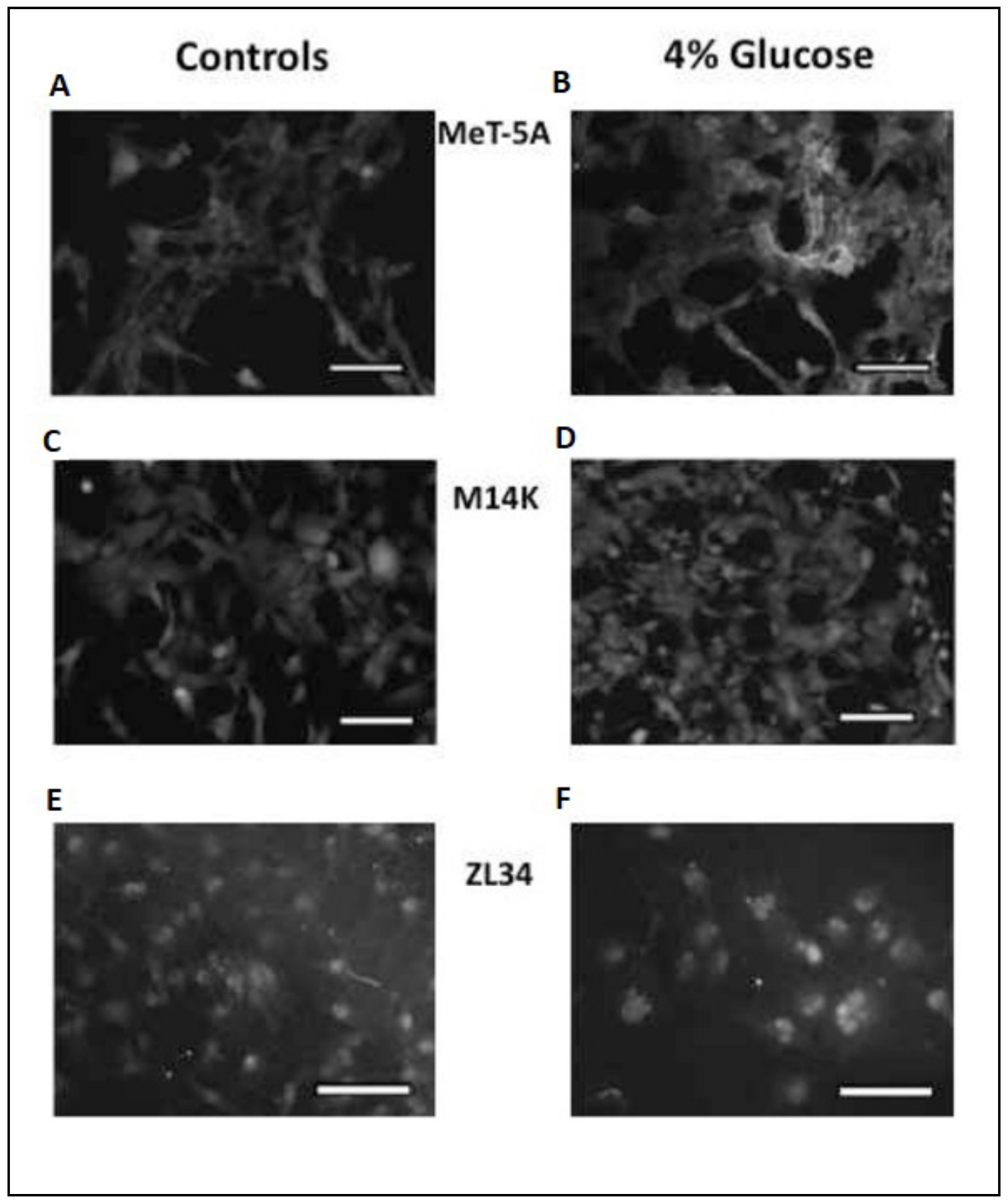

Fig. 4. Immuno-staining for AQP1 in MeT-5A, M14K, ZL34 cells in control (A, C, E) and high glucose hyperosmotic conditions (B, D, F) respectively. Scale bar is $50 \mu \mathrm{m}$. 


\section{Cellular Physiology Cell Physiol Biochem 2019;52:869-878 \\ \begin{tabular}{ll|l} 
and Biochemistry $\begin{array}{l}\text { DOl: 10.33594/000000060 } \\
\text { Published online: } 9 \text { April 2019 }\end{array}$ & $\begin{array}{l}\text { O } 2019 \text { The Author(s). Published by } \\
\text { Cell Physiol Biochem Press GmbH\&Co. KG }\end{array}$ \\
\cline { 2 - 3 }
\end{tabular} \\ Katkova et al.: Osmotic Water Permeability of Pleural Mesothelial Cells}

Control; Fig. 3B), in M14K cells the $\mathrm{P}_{\mathrm{f}}$ was reduced to $1.04 \mathrm{E}-03 \pm 0.86 \mathrm{E}-03 \mathrm{~cm} / \mathrm{sec}(\mathrm{n}=16$; $\mathrm{p}<0.001$ compared to Control; Fig. 3C). In the case of ZL34 MPM cells the $\mathrm{P}_{\mathrm{f}}$ was not reduced significantly (9.71E-04 $\pm 0.48 \mathrm{E}-04 \mathrm{~cm} / \mathrm{sec} ; \mathrm{n}=10 ; \mathrm{p}=0.09$ compared to Control; Fig. 3D).

$P_{f}$ effects of high glucose hyperosmotic stress for 24 hours in MeT-5A, M14K and ZL34 correspond to similar changes in the AQP1 protein expression as evidenced by immunofluorescence

In Fig. 4A-4F the intensity of AQP1 immunostaining of MeT-5A, M14K and ZL34 cells in control conditions (Fig. 4A, 4C and 4E respectively) and after high glucose induced hyperosmotic stress for 24 hours incubation with $4 \%$ glucose solution (Fig. 4B, 4D and 4F respectively). The intensity of staining is increased in MeT-5A cells, it is similar in M14K cells and it is reduced in ZL34 cells following the trend seen in the corresponding $\mathrm{P}_{\mathrm{f}}$ measurements.

\section{Discussion}

In this study we evaluated the differences in the $\mathrm{P}_{\mathrm{f}}$ of benign pleural mesothelial and epithelioid and sarcomatoid MPM cells. We found that in normal conditions, the $\mathrm{P}_{\mathrm{f}}$ of benign cells is significantly higher from both epithelioid and sarcomatoid type of MPM cells. However, the effect on $\mathrm{P}_{\mathrm{f}}$ was different in each cell line after their exposure to a hypertonic environment created by high glucose or mannitol for 24 hours prior to the experiment. Namely, the $P_{f}$ of benign cells increased significantly after the hyperosmotic stress, the $\mathrm{P}_{\mathrm{f}}$ of epithelioid MPM cells was unaffected while that of sarcomatoid MPM cells decreased significantly. Finally, these differences were reflected also after AQP1 immunostaining.

The $P_{f}$ values of mesothelial cells were significantly lower than that of other epithelial cells such as the kidney OMCD principal epithelial cells that we have previously assessed [23$25,27]$. This difference is expected because pleural mesothelial cells are normally facing a steady mucosal environment due to the stable composition of the pleural fluid in contrast to kidney OMCD principal epithelial cells that are challenged constantly with pro-urine of great variability in terms of osmolality (from 100-1400 $\mathrm{mOsm} \mathrm{kg}^{-1}$ ) [25]. Therefore, the kidney cells would be expected to have higher $\mathrm{P}_{\mathrm{f}}$ in order to adjust rapidly to drastic changes of the apical extracellular osmolality.

This is the first study describing differences in the $\mathrm{P}_{\mathrm{f}}$ between normal mesothelial and MPM cells. No other similar study exists in order to compare our findings, however a relevant study in human glioma showed that several cell lines maintain their AQP1 expression when grown in culture while others do not [28]. Also very few studies have investigated the AQP1 mediated $P_{f}$ differences in cancer cells by means of either silencing or inducing overexpression of AQP1 [28-31]. In all these studies as expected over-expression of AQP1 and silencing, increased and decreased respectively the $\mathrm{P}_{\mathrm{f}}$ of the studied cells. In such studies the loss of AQP1 results in the reduction of cell phenotypes that promote cancer processes such as angiogenesis, cell proliferation, migration and invasion. Indeed, one of the key functions that depend on the regulation of cell volume in cancer cells is that of cell migration and invasion [32]. In our experiments we speculate that the changes in the water permeability are mediated by changes in the expression levels of AQP1 and this notion is supported by our results regarding AQP1 immunostaining in MeT-5A cells.

However, in a previous study of our group we demonstrated that inhibition of AQP1 in the same cell lines used in the current experiments led to the inhibition of cell migration only in the ZL34 cell line [10]. One difference compared to the current study is the lower concentration of the AQP-1 inhibitor $\mathrm{HgCl}_{2}$ used $(0.01 \mathrm{mM}$ as compared to $0.1 \mathrm{mM}$ in the current study), that is much less cytotoxic but leads to nearly $40 \%$ inhibition of AQP1 water conductance as compared to $100 \%$ inhibition of AQP1 in the case of $0.1 \mathrm{mM}$ that is close to $100 \%[33]$. 


\section{Cellular Physiology Cell Physiol Biochem 2019;52:869-878 \\ \begin{tabular}{ll|l} 
and Biochemistry & $\begin{array}{l}\text { DOl: 10.33594/000000060 } \\
\text { Published online: } 9 \text { April 2019 }\end{array}$ & $\begin{array}{l}\text { O } 2019 \text { The Author(s). Published by } \\
\text { Cell Physiol Biochem Press GmbH\&Co. KG }\end{array}$ \\
\cline { 2 - 3 }
\end{tabular} \\ Katkova et al.: Osmotic Water Permeability of Pleural Mesothelial Cells}

As noted previously pleural mesothelial AQP1 is important since it mediates the faster resolution of aniso-osmotic pleural effusions with regards to the plasma of the pleural capillaries [14]. Regarding MPM, increased expression of AQP1 in biopsies of MPM patients has been shown to correlate with increased survival [16]. Additionally a specific pattern of expression was shown analogous to the histological subtype severity: higher AQP1 in epithelioid MPM with better prognosis than in sarcomatoid MPM with worse prognosis. How does AQP1 increased expression confer a survival advantage to MPM patients is not known, however it may have to do with the fact that it may lead to faster resolution of pleural effusion in MPM that reduce the capacity of the tumor to spread in the thoracic cavity [10, 17]. Diabetes is a common comorbidity in MPM therefore, the differential response of M14K and ZL34 cells in terms Pf and AQP1 expression due to high glucose hyperosmotic stress indicates impairment in the mechanism that regulates AQP1 expression and water permeability in M14K and ZL34 cells and potentially may be of clinical importance [20]. Based on our experimental approach we cannot speculate on the clinical relevance of such findings, however they indicate that there is a cellular mechanism that regulates water permeability as response to high tonicity and/or high glucose extracellular environment. This hypothesis requires further study especially under the rationale that several malignancy promoting cell phenotypes depend on the effective cell volume regulation.

\section{Conclusion}

In conclusion we have demonstrated that there is a difference in the Pf of benign mesothelial, epithelioid and sarcomatoid MPM cells. Furthermore, hyperosmotic stress yields different responses in each cell type that was accompanied by corresponding changes in the expression of AQP1. Further studies are needed for the dissection of the molecular events that mediate our findings.

\section{Acknowledgements}

The work was supported by Project \# 0324-2019-0041 of the Russian Government Budget and Grant RFBR (Russian Foundation of Basic Research) \#17-04-00328.

\section{Disclosure Statement}

The authors declare no conflicts of interest.

\section{References}

- 1 Lai-Fook SJ: Pleural mechanics and fluid exchange. Physiol Rev 2004;84:385-410.

- 2 Agostoni E, Zocchi L: Pleural liquid and its exchanges. Respir Physiol Neurobiol 2007;159:311-323.

- 3 Zarogiannis SG, Kalomenidis I: Can pharmacologic agents speed up the rate of resorption of pleural fluid? Curr Opin Pulm Med 2015;21:372-375.

4 Hooper C, Gary Lee YC, Maskell N, on behalf of the BTS Pleural Guideline Group: Investigation of a unilateral pleural effusion in adults: British Thoracic Society pleural disease guideline 2010. Thorax 2010;65:ii4-ii17.

5 Kotsiou OS, Zarogiannis SG, Gourgoulianis KI: Prehospital NSAIDs use prolong hospitalization in patients with pleuro-pulmonary infection. Respir Med 2017;123:28-33.

6 Tsilioni I, Filippidis AS, Kerenidi T, Budanov AV, Zarogiannis SG, Gourgoulianis KI: Sestrin-2 is significantly increased in malignant pleural effusions due to lung cancer and is potentially secreted by pleural mesothelial cells. Clin Biochem 2016;49:726-728. 


\section{Cellular Physiology Cell Physiol Biochem 2019;52:869-878

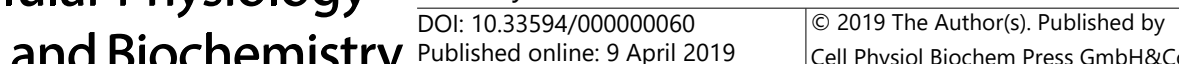 and Biochemistry Published online: 9 April 2019 Cell Physiol Biochem Press GmbH\&Co. KG \\ Katkova et al.: Osmotic Water Permeability of Pleural Mesothelial Cells}

- 7 Vavougios G, Kerenidi T, Tsilioni I, Zarogiannis SG, Gourgoulianis KI: Pleural effusion levels of DJ-1 are increased in elderly lung cancer patients with malignant pleural effusions. Redox Rep 2015;20:254-258.

- 8 Zarogiannis SG, Tsilioni I, Hatzoglou C, Molyvdas PA, Gourgoulianis KI: Pleural fluid protein is inversely correlated with age in uncomplicated parapneumonic pleural effusions. Clin Biochem 2013;46:378-380.

9 Arsenopoulou ZV, Taitzoglou IA, Molyvdas PA, Gourgoulianis KI, Hatzoglou C, Zarogiannis SG: Silver nanoparticles alter the permeability of sheep pleura and of sheep and human pleural mesothelial cell monolayers. Environ Toxicol Pharmacol 2017;50:212-215.

10 Jagirdar RM, Apostolidou E, Molyvdas PA, Gourgoulianis KI, Hatzoglou C, Zarogiannis SG: Influence of AQP1 on cell adhesion, migration, and tumor sphere formation in malignant pleural mesothelioma is substratumand histological-type dependent. Am J Physiol Lung Cell Mol Physiol 2016;310:489-495.

11 Peppa VI, Arsenopoulou ZV, Zarogiannis SG, Deligiorgi T, Jagirdar R, Makantasis I, Stefanidis I, Liakopoulos V, Molyvdas PA, Gourgoulianis KI, Hatzoglou C: VEGF increases the permeability of sheep pleura ex vivo through VEGFR2 stimulation. Cytokine 2014;69:284-288.

12 Zarogiannis S, Hatzoglou C, Stefanidis I, Matafia G, Vogiatzidis K, Gourgoulianis K, Molyvdas PA: Effect of adrenaline on transmesothelial resistance of isolated sheep pleura. Respir Physiol Neurobiol 2006;150:165-172.

13 Zolak JS, Jagirdar R, Surolia R, Karki S, Oliva O, Hock T, Guroji P, Ding Q Liu RM, Bolisetty S, Agarwal A, Thannickal VJ, Antony VB: Pleural mesothelial cell differentiation and invasion in fibrogenic lung injury. Am J Pathol 2013;182:1239-1247.

14 Song Y, Yang B, Matthay MA, Ma T, Verkman AS: Role of aquaporin water channels in pleural fluid dynamics. Am J Physiol Cell Physiol 2000;279:1744-1750.

- 15 Driml J, Pulford E, Moffat D, Karapetis C, Kao S, Griggs K, Henderson DW, Klebe S: Usefulness of Aquaporin 1 as a Prognostic Marker in a Prospective Cohort of Malignant Mesotheliomas. Int J Mol Sci 2016;17:1041.

- 16 Kao SC, Armstrong N, Condon B, Griggs K, McCaughan B, Maltby S, Wilson A, Henderson DW, Klebe $\mathrm{S}$ : Aquaporin 1 is an independent prognostic factor in pleural malignant mesothelioma. Cancer 2012;118:2952-2961.

17 Jagirdar R, Solenov EI, Hatzoglou C, Molyvdas PA, Gourgoulianis KI, Zarogiannis SG: Gene expression profile of aquaporin 1 and associated interactors in malignant pleural mesothelioma. Gene 2013;517:99-105.

18 Klebe S, Griggs K, Cheng Y, Driml J, Henderson DW, Reid G: Blockade of aquaporin 1 inhibits proliferation, motility, and metastatic potential of mesothelioma in vitro but not in an in vivo model. Dis Markers 2015;2015:286719.

19 Lai KN, Li FK, Lan HY, Tang S, Tsang AW, Chan DT, Leung JC: Expression of aquaporin-1 in human peritoneal mesothelial cells and its upregulation by glucosein vitro. J Am Soc Nephrol 2001;12:1036-1045.

20 Wu H, Walker J, Damhuis RA, Brewster DH, Wild SH; Scottish Diabetes Research Network Epidemiology Group: Metformin and survival of people with type 2 diabetes and pleural mesothelioma: A populationbased retrospective cohort study. Lung Cancer 2016;99:194-199.

21 Chertow BS, Kadzielawa R, Burger AJ: Benign pleural effusions in long-standing diabetes mellitus. Chest 1991;99:1108-1111.

22 Solenov E, Watanabe H, Manley GT, Verkman AS: Sevenfold-reduced osmotic water permeability in primary astrocyte cultures from AQP-4-deficient mice, measured by a fluorescence quenching method. Am J Physiol Cell Physiol 2004;286:C426-C432.

23 Solenov EI, Baturina GS, Katkova LE, Zarogiannis SG: Methods to Measure Water Permeability. Adv Exp Med Biol 2017;969:263-276.

24 Katkova LE, Baturina GS, Ilyaskin AV, Zarogiannis SG, Solenov EI: The water permeability reduction after successive hypo-osmotic shocks in kidney principal cells is apically regulated. Cell Physiol Biochem 2014;34:1802-1811.

25 Zarogiannis SG, Ilyaskin AV, Baturina GS, Katkova LE, Medvedev DA, Karpov DI, Ershov AP, Solenov EI: Regulatory volume decrease of rat kidney principal cells after successive hypo-osmotic shocks. Math Biosci 2013;244:176-187.

26 Solenov EI, Nesterov VV, Baturina GS, Khodus GR, Ivanova LN: Effect of dAVP on basolateral cell surface water permeability in the outer medullary collecting duct. Eur Biophys J 2003;32:614-619.

27 Baturina GS, Katkova LE, Zarogiannis SG, Solenov EI: Brattleboro rats have impaired apical membrane water permeability regulation in the outer medullary collecting duct principal cells. Clin Exp Pharmacol Physiol 2016;43:1225-1233. 


\section{Cellular Physiology Cell Physiol Biochem 2019;52:869-878}

\begin{tabular}{ll|l} 
and Biochemistry 10.33594/000000060 & $\begin{array}{l}\text { O } 2019 \text { The Author(s). Published by } \\
\text { Cell Physiol Biochem Press GmbH\&Co. KG }\end{array}$ \\
\cline { 2 - 3 } & Published online: 9 April 2019
\end{tabular}

Katkova et al.: Osmotic Water Permeability of Pleural Mesothelial Cells

28 McCoy E, Sontheimer H: Expression and function of water channels (aquaporins) in migrating malignant astrocytes. Glia 2007;55:1034-1043.

- 29 Hu J, Verkman AS: Increased migration and metastatic potential of tumor cells expressing aquaporin water channels. FASEB J 2006;20:1892-1894.

- 30 Jiang Y: Aquaporin-1 activity of plasma membrane affects HT20 colon cancer cell migration. IUBMB Life 2009;61:1001-1009.

- 31 Saadoun S, Papadopoulos MC, Hara-Chikuma M, Verkman AS: Impairment of angiogenesis and cell migration by targeted aquaporin-1 gene disruption. Nature 2005;434:786-792.

- 32 Verkman AS: Aquaporins at a glance. J Cell Sci 2001;124:2107-2112.

- 33 Yang B, Kim JK, Verkman AS: Comparative efficacy of $\mathrm{HgCl} 2$ with candidate aquaporin-1 inhibitors DMSO, gold, TEA+ and acetazolamide. FEBS Lett 2006;580: 6679-6684. 